
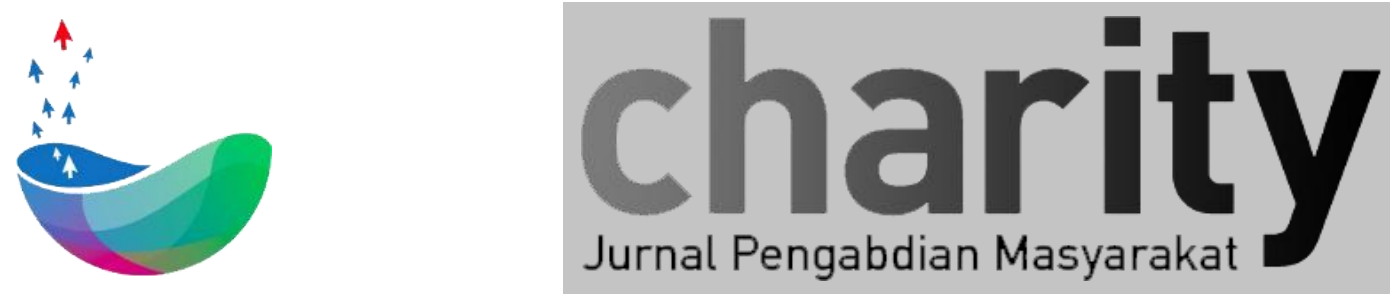

\title{
Video 360 Sebagai Media Promosi Produk Mitra UMKM Kabupaten Bandung
}

\author{
Anggar Erdhina Adi S.Sn.,M.Ds. ${ }^{1}$, Mario S.Ds.,,M.Ds. ${ }^{2}$, \\ Desain Komunikasi Visual, Fakultas Kreatif Industri, Universitas Telkom \\ Desain Komunikasi Visual, Fakultas Kreatif Industri, Universitas Telkom \\ Desain Komunikasi Visual, Fakultas Kreatif Industri, Universitas Telkom \\ * anggarwarok@telkomuniversity.ac.id,dsmario@telkomuniversity.ac.id,
}

\section{INFO ARTIKEL}

Diterima 09 Desember 2020

Direvisi 10 Agustus 2021

Disetujui 06 Desember 2021

Tersedia Online 4 Februari 2022

\begin{abstract}
ABSTRAK
Kegiatan ini bertujuan untuk : 1) Mengaplikasikan Keilmuan kepada Masyarakat; 2) Meningkatkan Pengetahuan \& Pemahaman video produk dengan teknik 360 untuk Binaan Dinas Koperasi dan UMKM Kabupaten Bandung 3. Meningkatkan kemampuan anggota komunitas, khususnya untuk meningkatkan kualitas video produk. 4. Mendorong Produktivitas Anggota UMKM Binaan Dinas Koperasi dan UMKM Kabupaten Bandung untuk meningkatkan kualitas video produknya. Adapun ringkasan kegiatan dari program ini adalah, memberikan diseminasi informasi serta pelatihan mengenai fungsi dan penerapan video produk dengan menggunakan teknik 360 pada produk Binaan Dinas Koperasi dan UMKM Kabupaten Bandung, agar mampu meningkatkan kualitas materi untuk promosi dan kemasan produk UMKM.
\end{abstract}

Keyword: video 360, media promosi, UMKM.

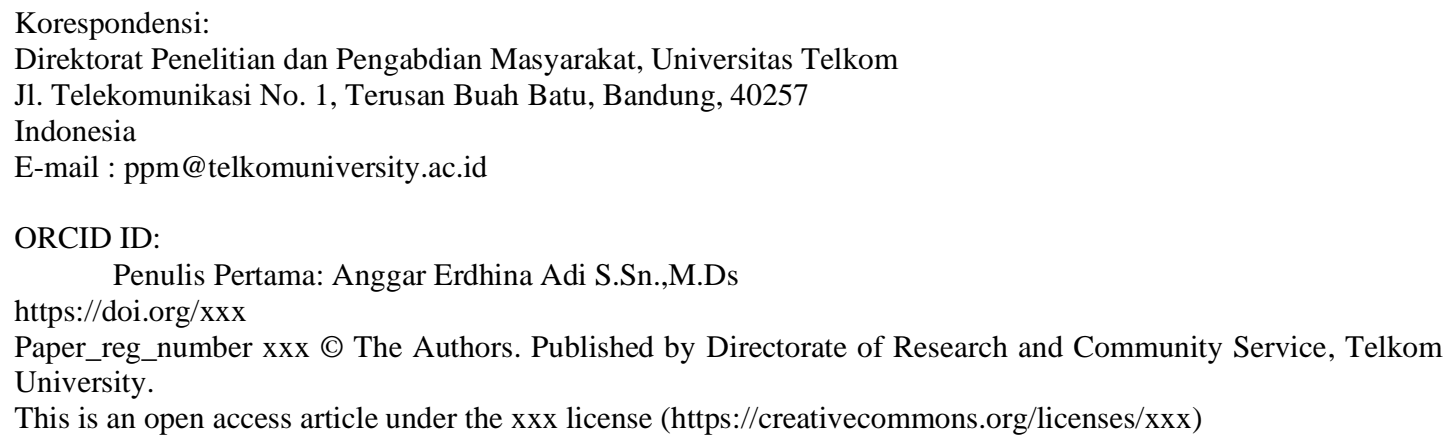




\section{Pendahuluan}

Video 360 merupakan video yang dibuat dengan teknik pengambilan gambar dan olah kamera yang secara bersamaan merekam arah secara keseluruhan dengan rotasi 360 derajat, penonton dapat menggeser dan memutar sudut pandang 360 video untuk menonton dari sudut yang berbeda (Rambing et al, 2017).

Menurut Highton (2010) dewasa ini, foto ataupun video sudah menjadi bentuk media mainstream yang dipakai untuk kebutuhan promosi sebuah produk, karena dapat memberikan informasi terkait dengan produk yang akan di jual secara online. Penjualan produk secara online sudah menjadi kebiasaan baru bagi sebagian masyarakat di Indonesia, terbukti dengan banyaknya pilihan toko online sebagai penyedia wadah bagi siapa saja yang ingin menjadi penjual suatu produk secara online .

Permasalahan yang sering terjadi adalah, kesalahpahaman antara penjual dan pembeli ketika pembeli sudah membeli barang yang didapat secara online, namun barang yang diterima tidak sesuai dengan apa yang mereka lihat dari foto ataupun video produk tersebut (Ishak, 2012). Jika ditinjau kembali, fenomena tersebut dikarenakan penjual tidak mendapatkan informasi yang lebih detail terkait produk yang mereka inginkan, karena sangat berbeda jika pembeli datang langsung ke toko dan melihat langsung produk tersebut dari berbagai sisi, sebuah foto produk kurang dapat melakukan hal tersebut.

Namun dengan adanya video 360 , produk yang dijual secara online, dapat ditampilkan secara keseluruhan dengan menampilkan setiap sisinya. Hal ini dapat meminimalisir kesalahan informasi yang diterima oleh pembeli, dan penjual tidak akan mendapatkan respon buruk terkait dari produk yang dijualnya. Dengan begitu UKM yang ingin menjual baranganya di toko online dapat menerapkan teknik tersebut, karena disamping manfaatnya yang cukup besar juga memberikan pengalaman menarik bagi pembeli yang ingin membeli barang tersebut.

Salah satu anggota UMKM Binaan Dinas Koperasi dan UMKM Kabupaten Bandung, bergerak dalam jasa fotografi adalah Lensa Pangalengan. Dengan menambahkan wawasan dan keterampilan terkait dengan video 360 dapat meningkatkan daya saing dalam kategori pembuatan konten promosi produk. Melihat adanya potensi ini, maka dibuatlah "Pelatihan Pembuatan Video Produk 360 untuk UMKM di Dinas Koperasi dan UMKM Kabupaten Bandung" dengan tujuan untuk meningkatkan keterampilan dalam pembuatan konten promosi produk dalam bentuk video 360 .
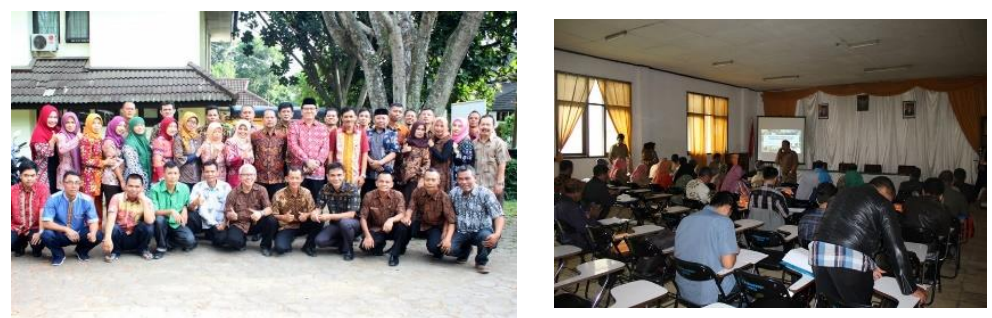

Gambar 1. Lokasi tempat Abdimas (a) dan Aktifitas mitra (b) 
Berdasarkan pengamatan dan kunjungan kepada calon mitra melalui observasi dan wawancara dengan Dinas Koperasi dan UMKM Kabupaten Bandung, kebanyakan masyarakat masih kesulitan mengemas video produknya. Keterbatasan pengetahaun dan alat untuk mempraktekkan menjadi salah satu kendala yang dihadapi olehmitra.

Dengan berkembangnya era digital dan promosi melalui berbagai saluran digital, maka mau tidak mau para pelaku dalam UKM Binaan Dinas Koperasi dan UMKM Kabupaten Bandung ini merasa kesulitan untuk mengemas video produknya. Namun, tak bisa dipungkiri jika keterbatasan peralatan juga menjadi salah satu pertimbangan kesulitan para pelaku untuk menghasilkan video produk yang berkualitas. Selama ini para pelaku UKM di Binaan Dinas Koperasi dan UMKM Kabupaten Bandung hanya mengandalkan ilmu secara otodidak, sehingga hasilnya tidak selalu maksimal. Melihat kondisi tersebut maka permasalahan pengembangan kemampuan untuk menghasilkan video produk UKM tersebut menjadi sangat urgent untuk para pelaku tersebut.

\section{Metode Pelatihan}

Berdasarkan latar belakang Tri Dharma sebagai dosen menjadikan kegiatan Abdimas ini sebagai upaya pemanfaatan potensi yang dimiliki oleh mitra dalam bentuk kerja sama dengan kampus Universitas Telkom. Melalui metode pengembangan wawasan dan keahlian khusus dalam bidang teknis pembuatan konten video 360 diharapkan bermanfaat bagi mitra UMKM yang ingin mempromosikan produknya ke toko online. 
Input : Perkembangan teknologi informasi mengakibatkan bentuk promosi produk menjadi digital dan inovatif. namun para pegiat UKM dan pelakuusaha mikro kurang jeli dengan perkembangan era digital yang lebih mengutamakan visual. Salah satu cara mengenalkan dan mempromosikan adalah melalui

Proses : tim PKM memberikan pelatihan untuk membuat materi ajar yang menarik khususnya dalam proses produksi (video dengan Teknik 360), diharapkan bisa membantu para pegiat UKM, pengusaha mikro dan dalam membantu mengemas produk mereka dalam video yang menarik dan kreatif.

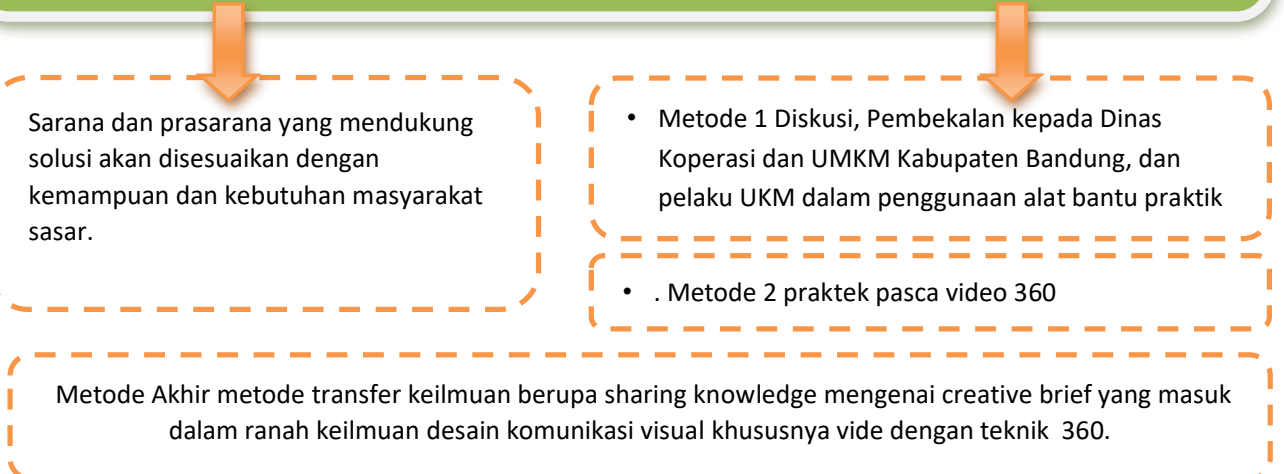

\section{OUPUT}

Luaran : transfer ilmu dari keilmuan yang dikembangkan tim dosen Program Studi DKV berupa hasil vide dengan teknik 360
Manfaat Luaran: kegiatan pelatihan ini dapat membantu salah satu program pemerintah Kabupaten Bandung untuk mengembangkan potensi dan profesionalisme dalam mengemas visual produk mereka. Kegiatan pelatihan ini diharapkan mampu meningkatkan kreatifitas khususnya UKM Binaan Dinas Koperasi dan UMKM Kabupaten Bandung.

Gambar 2. Gambaran IPTEK yang ditransfer ke mitra.

\subsection{Wawancara dan Survei Mitra Pengabdian pada Masyarakat}

Proses pencarian data dan informasi mengenai mitra pengabdian pada masyarakat dimulai semenjak bulan Juni 2020. Pada saat itu ketua Abdimas melakukan diskusi secara daring dengan Bapak Daryanto selaku ketua UMKM, dikarenakan keadaan pandemi Covid yang tidak memungkinkan untuk bertemu secara langsung. Dari tahap ini didapatkanlah informasi awal mengenai mitra untuk merumuskan materi kegiatan pengabdian pada masyarakat.

Pada tahap penyelesaian administrasi perijinan, dilakukan legalitas kegiatan dengan penandatanganan surat kesediaan menjadi mitra pelaksanaan kegiatan pengabdian pada masyarakat secara daring. Kemudian proses 
selanjutnya yaitu dilakukan finalisasi proposal untuk diajukan ke pihak PPM Telkom University.

\subsection{Penyusunan Materi}

Setelah proses administrasi selesai, kemudian dilakukan penyusunan materi. Materi pelatihan berfokus pada wawasan terkait media promosi produk menggunakan video 360 , teknis dan cara pembuatan konten video produk 360 dalam rangka menunjang kegiatan promosi produk yang dilakukan oleh UKM. Praktik langsung akan dilakukan secara tatap muka, dengan menggunakan laboratorium Green Screen Fakultas Industri Kreatif Telkom University. Selain itu materi tersebut juga dikemas dalam bentuk PPT, dengan harapan dapat dipelajari secara mandiri dan berkala. Kegiatan pelatihan ini memiliki potensi untuk dilanjutkan setiap tahunnya dengan pemberian materi yang berbeda, namun masih berkaitan dengan bidang media promosi produk.

Beberapa poin materi yang disampaikan pada pelatihan ini yaitu:

1. Mengenalkan apa itu video 360.

2. Menjelaskan manfaat video 360 sebagai media promosi.

3. Menjelaskan prilaku konsumen toko online.

4. Menjelaskan peralatan/tools pembuatan video 360,

5. Menjelaskan teknik pengambilan gambar 360 ,

6. Menjelaskan cara menyunting video 360 menggunakan smartphone

7. Menjelaskan cara mempublikasi hasil video 360 ke social media.
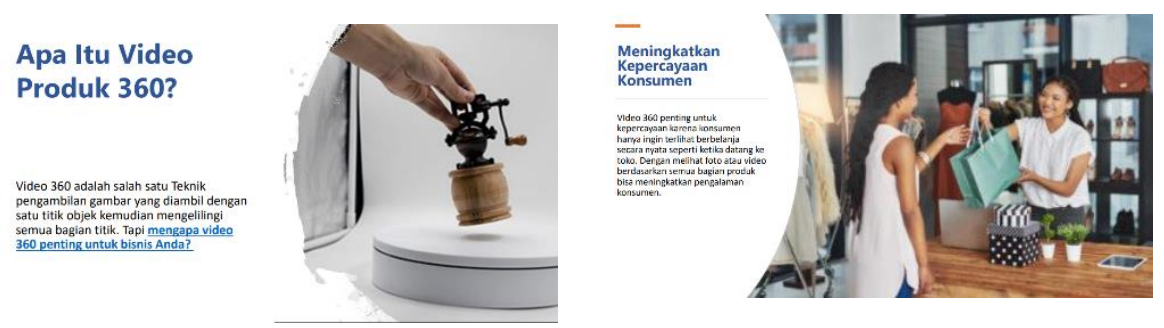

Gambar 4. Video tutorial PowerPoint, Pembuka (a) dan Materi (b)

\section{Analisa \& Hasil Kegiatan}

Pelaksanaan kegiatan pengabdian pada masyarakat berupa "Pelatihan Pembuatan Video Produk 360 untuk UMKM di Dinas Koperasi dan UMKM Kabupaten Bandung" dilakukan pada:

Hari, tanggal : Senin, 26 Oktober 2020

Pukul

: $10.00 \mathrm{WIB}$ - selesai

Lokasi

: Laboratorium Green Screen, Fakultas Industri Kreatif Telkom University. Jl. Telekomunikasi No. 1, Terusan Buahbatu - Bojongsoang, Sukapura, Kec. Dayeuhkolot, Bandung, Jawa Barat 40257. 
Melalui metode pengembangan wawasan dan keahlian khusus dalam bidang teknis pembuatan konten video 360 diharapkan bermanfaat bagi mitra UMKM yang ingin mempromosikan produknya ke toko online

Pelatihan ini dihadiri oleh 10 mitra pelaku UKM dari Lensa Pangalengan. Mitra akan diundang pada pelatihan dalam pengabdian ini berupa pengumuman ataupun penyebaran surat. Masyarakat mitra diminta membawa peralatan berupa smartphone sebagai alat yang dapat mereka gunakan untuk pelatihan. Mereka akan diberikan pengetahuan secara lisan dari pengabdi dengan menggunakan media powerpoint presentation sebagai pendukung. Setelah itu peserta akan melakukan praktek sesuai dengan apa yang dijadikan materi pelatihan.

\section{Kesimpulan dan Saran}

Evaluasi pelaksanaan program adalah membagikan keilmuan yang kamimiliki untuk diteruskan kepada masyarakat. Dalam hal ini dipilih para UKM Binaan Dinas Koperasi dan UMKM Kabupaten Bandung dengan harapan, melalui kegiatan pelatihan ini dapat membantu pengembangan potensi UKM melalui Dinas Koperasi dan UMKM Kabupaten Bandung di provinsi Jawa Barat untuk meningkatkan promosi dalam format soft selling melalui video 360 yangdihasilkan.

Keberlanjutan program setelah kegiatan dilaksanakan materi yang dipaparkan dapat diimplementasikan pada produknya, apabila terlaksana dengan baik, diharapkan lembaga yang menaungi kami (Universitas Telkom) akan membantu lebih lanjut guna mensukseskan program ini untuk masa yang akan datang. Kami mengharapkan anggota, pelaku usaha dan Dinas Koperasi dan UMKM Kabupaten Bandung untuk dapat berpartisipasi dalam kegiatan ini yang kemudian berlanjut dengan topik lain dari Desain Komunikasi Visual Universitas Telkom 
$\square$ Charity Jurnal Pengabdian Masyarakat Vol.05 No.01 (2022)

\section{DAFTAR PUSTAKA}

[1] Highton. S, 2010. Paper of Virtual Reality Photography - Creating Panoramic and Object Images. China: Library of Congress.

[2] Ishak. A, 2012. Analisi Kepuasan Pelanggan Dalam Belanja Online, E-Jurnal, Fakultas Ekonomi Universitas Islam Indonesia.

[3] Rambing, et al, 2017. Virtual Reality Berbasis Video 360 Derajat pada Tari-Tarian Adat Suku Minahasa, E-Jurnal, Teknik Informatika Universitas Sam Ratulangi Manado, Indonesia. 